Uneasy Warriors 
This page intentionally left blank 


\section{Uneasy Warriors}

Gender, Memory, and Popular Culture in the Japanese Army

Sabine Frühstück

무

UNIVERSITY OF CALIFORNIA PRESS

Berkeley • Los Angeles • London 
University of California Press, one of the most distinguished university presses in the United States, enriches lives around the world by advancing scholarship in the humanities, social sciences, and natural sciences. Its activities are supported by the UC Press Foundation and by philanthropic contributions from individuals and institutions. For more information, visit www.ucpress.edu.

University of California Press

Berkeley and Los Angeles, California

University of California Press, Ltd.

London, England

(C) 2007 by The Regents of the University of California

Every effort has been made to identify and locate the rightful copyright holders of all material not specifically commissioned for use in this publication and to secure permission, where applicable, for reuse of all such material. Credit, if and as available, has been provided for all borrowed material either on-page, on the copyright page, or in an acknowledgment section of the book. Errors, omissions, or failure to obtain authorization with respect to material copyrighted by other sources has been either unavoidable or unintentional. The author and publisher welcome any information that would allow them to correct future reprints.

\section{Library of Congress Cataloging-in-Publication Data}

\section{Frühstück, Sabine.}

Uneasy warriors : gender, memory, and popular culture in the Japanese Army / Sabine Frühstück.

$$
\text { p. } \mathrm{cm} \text {. }
$$

Includes bibliographical references and index.

ISBN 978-0-520-24794-9 (cloth : alk. paper)ISBN 978-0-520-24795-6 (paper : alk. paper)

I. Japan-Armed Forces. 2. Sociology, MilitaryJapan. 3. Popular culture-Japan. 4. JapanArmed Forces-Women. I. Title.

$$
\begin{aligned}
& \text { UA8 45.F68 } 2007 \\
& 306.2^{\prime} 70952 \text {-dc22 }
\end{aligned}
$$

2007011432

Manufactured in the United States of America

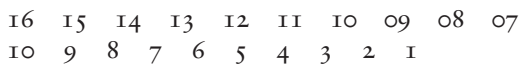

This book is printed on New Leaf EcoBook 60, a I00\% recycled fiber of which $60 \%$ is de-inked postconsumer waste, processed chlorine-free. EcoBook 60 is acid-free and meets the minimum requirements of ANSI/ASTM D5634-OI (Permanence of Paper). 